\title{
Cervical cancer prevention in Pernambuco: improvements for whom? Inequity scenario in the state of the Northeast Region
}

Keila Silene de Brito e Silva 1

D https://orcid.org/0000-0002-0291-0708

Antonio Flaudiano Bem Leite 2

https://orcid.org/0000-0003-0211-6608

Deise Maria da Conceição Silva 3

https://orcid.org/0000-0002-5760-2833

Oswaldo Yoshimi Tanaka 4

https://orcid.org/0000-0002-5653-0794
Marilia Cristina Prado Louvison 5

iD https://orcid.org/0000-0003-1630-3463

Adriana Falangola Benjamin Bezerra 6

iD https://orcid.org/0000-0002-5278-3727

1 Núcleo de Saúde Coletiva. Centro Acadêmico de Vitória. Universidade Federal de Pernambuco. R. Alto do Reservatório, s.n. Bela Vista. Vitória de Santo Antão, PE, Brasil. CEP: 55.608-680. E-mail: britokeila@hotmail.com

2 Vigilância em Saúde. Secretaria de Saúde de Vitória de Santo Antão. Vitória de Santo Antão, PE, Brasil.

3 Residência Multiprofissional em Atenção Básica e Saúde da Família. Associação Caruaruense de Ensino Superior. Caruaru, PE, Brasil

4,5 Departamento de Política, Gestão e Saúde. Faculdade de Saúde Pública. Universidade de São Paulo. São Paulo, SP, Brasil.

6 Departamento de Medicina. Centro de Ciência da Saúde. Universidade Federal de Pernambuco. Recife, PE, Brasil.

\section{Abstract}

Objectives: to analyze the access to cervical cancer preventive examination in Pernambuco between 2002 and 2015 by cytopathological exam coverage.

Methods: public data from SUS Computer Department were used, then processed by Tabnet and Excel and calculated the slope of the over time coefficient trend by simple regression techniques. Afterwards, they were plotted in thematic maps covering cytopathological exams on Terraview app 4.2.2.

Results: Pernambuco State presented an increase of exam coverage trend in all the health regions until 2010. Since that year it started to have stabilization and decreased the tendency. Comparing the coverage of the two first years, in 2002, 42.7\% of the cities coverage was below 0.2 and in 2015 the scenario changed, 41.1\% of the cities coverage was above 0.6. We emphasize that even in that same year $13.5 \%$ of the cities still had a low or too low coverage (less than 0.4). The over time trends in increase and decline were strongly meaningful.

Conclusions: this study revealed that all health regions presented a coverage lower than recommended, in some period or in all of them, even with the State growth tendency it demonstrated an unequal and heterogeneous characteristic.

Key words Health indicators, Social inequity, Healthcare accessibility, Technical report

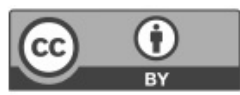




\section{Introduction}

In Brazil, cervical cancer is the third kind of cancer with highest incidence among women, apart from non-melanoma skin cancer. ${ }^{1}$ At the same time, it represents one of the highest prevention potential and cure, as long as it is early diagnosed.

The high prevention potential and cure might be justified by the fact that it is a slow-evolutional disease, with well delimited stages and easily detected in terms of alteration even in its early stage, which promotes early diagnosis and effective treatment. 2,3

In Brazil, cervical cancer epidemiological context is very heterogenous. When analyzing the regions in the country, the highest incidence is in the North $(26.24 / 100,000)$, along with the Northeast $(16.10 / 100,000)$ and the Midwest $(12.35 / 100,000)$ regions. Both the South $(12.60 / 100,000)$ and Southeast $(8.61 / 100,000)$ present lower incidences. 1

Recent studies ${ }^{4}$ analyzed the over time tendency on cervical cancer mortality nationwide and calculated its projections up to 2030, pointing out that the South, Southeast and Midwest demonstrated a significant tendency of decreasing, thus, the Northeast presented in 10 years (1996 through 2006) a rising trend, followed by a stability. About projections for 2030, an opposite national tendency of mortality reduction for this type of cancer, in the North and Northeast regions will follow the highest rates, maintaining the inequality in the country.

The investment to reduce the occurrence and the mortality rates on cervical cancer began in 1998 with the creation of the Programa Nacional de Combate ao Cancer de Colo Uterino (National Combat on Cervical Cancer Program). Among the actions of the program, one of the most effective strategies for its control is cancer screening and its precursor lesions by performing the cervical cytopathology tests. 5 The Health Ministry along with the Instituto Nacional de Controle de Câncer (INCA) (Nation Institute of Cancer Control), emphasizes the necessity of this exam to be performed annually, prioritizing 25-to64-year-old women, but after two consecutive years of negative exams, and it can be performed every three years. ${ }^{6}$

The World Health Organization says that achieving a coverage of $80 \%$, associated with treatment in the early stages resulting in a reduction of up to $90 \%$ in the occurrence rates of cervical cancer. ${ }^{7}$

In order to strengthen the health system, the Pacto pela Saúde (Pact for Health) program was released in 2006, in which a setting of commitments were organized in the federative entities defining its three guidelines: Pacto pela Vida, em Defesa do SUS $e$ de Gestão (Pact for life in defense of the Public Health System and the Management). In the first guideline, to control cervical cancer was included as one of the agreed priorities. ${ }^{8}$

In 2011, the Federal Decree no. 7,508/2011 institutionalizes the Contrato Organizativo da Ação Pública da Saúde (COAP) (Public Health Organizational Action Contract) and reinforces collaboration agreements stablished among the federal entities in view to organize and integrate actions and health services through agreed indicator and goals of assessing criteria performance. ${ }^{9}$

In that perspective, in 2014, the Secretaria Estadual de Saúde de Pernambuco (SES/PE) (State Health Secretary of Pernambuco) released a Caderno de Metas e Resultados dos Indicadores do Pacto/COAP (Goals and Results Report of the Pact Indicators/COAP), and undertakes 64 indicators as priorities, among them is: "the reason for cervical cancer cytopathological exams should be performed on women aged between 25 to 64 years old as well as in the female population in the same age group". The referred indicator is universal and contributes to the access of preventive cervical cancer examination assessment, which allows to identify situations that demands interventions, besides subsidizing policy planning, management and assessment aiming for this specific group. 10

In 2008-2011 the Plano Estadual de Saúde (PES) (State Health Plan), as well as in 2011-2015 in the State of Pernambuco asserts its commitment by registering the goals for planning, promoting, coordinating, supporting and supervising in a state level, to guarantee the reviewed and programmed actions focusing on women's health, upon enforcement of the guidelines which included female morbitity and mortality reduction, especially by inevitable causes, as well as the control on cervical and breast cancer. 11,12

Given the magnitude problem of cervical cancer and the commitments agreed on by the State of Pernambuco, it is important to present how the access to preventive cervical cancer examination outlines over time in the State.

\section{Women's access to preventive examination: an analytical look}

In order to analyze the access of preventive examination in the State of Pernambuco, a quantitative approach study was carried out considering the cytopathological exam coverage in the period of 2002 to 2015. 
The State of Pernambuco with 9.3 millions inhabitants is located on the Northest region of Brazil. It is extended in a territory of more than $98,000 \mathrm{~km}^{2}$ long, with 184 cities and towns including the insular district State of Fernando de Noronha. ${ }^{13}$ The Health Regions in the State are distributed into 4 macroregions (Figure 1).

These regions are geographically made up with bordering cities and towns that have social, economical and cultural similaries, share communication and transport networks, whose goal is to integrate the organization, into planning and executing health actions and services. The macroregions are territorial organizations composed by the Health Regions with the objective of offering medium and high complexity services, that is, procedures or actions that require higher technological complexity and overload the capacity of a single region. 13

An evaluative indicator coverage was used: "the relationship between the number of cytopathological cervical examinations in women aged 25 to 64 years old, in a certain city and year, having as a denominator of female population in the same age group of 25 to 64 years old, in the same place and year divided by 3.14

Since this is a thirteen-year historical series about a procedure that had, during this period, its registration on different information systems (Siscolo, Siscan, SIA), there was an option to use calculation methods and available and elaborated database by the Health Ministry at SUS (Public Health System $)^{5}$ Computer Department in order to avoid biases. By doing so, the chronologies of the following programs were analyzed: Pactos de Atenção Básica, (Pact for Basic Care), Pacto pela Saúde - 2010/2011, (Pact for Health), Transição Pacto pela Saúde e COAP - 2012 e Rol de Diretrizes (Pact on Health Transition and COAP - 2012 and the Guideline List), Objetivos, Metas e Indicadores 2013-2015 (Goals, Objectives and indicators) in its yearly editions in 2013, 2014 and 2015.

Data tabulation was done by Tabnet software and afterwards were exported and processed in an electronic Excel ${ }^{\circledR}$ spreadsheet, organized and consolidated in the only database indicator. Statistic measures were produced: coefficient regression of the over ime trend of the regression line and the significance test ( $F$ Test) for all the cities and towns in this State.

To check the over time trend of the cervical cancer coverage evaluative indicator, a simple linear regression model was applied by the formula of: $Y=\alpha+\beta \mathrm{X}$, where $Y$ is a dependent variation, represented by the indicator, and $\mathrm{X}$ is the independent variable, represented by the year of the indicator coverage assessment. To test the significance ( $p$ value), the cut-off point was 0.05 of the regression analysis, either for the $F$-Test and the $T$-Test, was confirmed by the respective confidence intervals (CI95\%). 16

Figure 1

Health regions and macroregions. Pernambuco, 2014.13

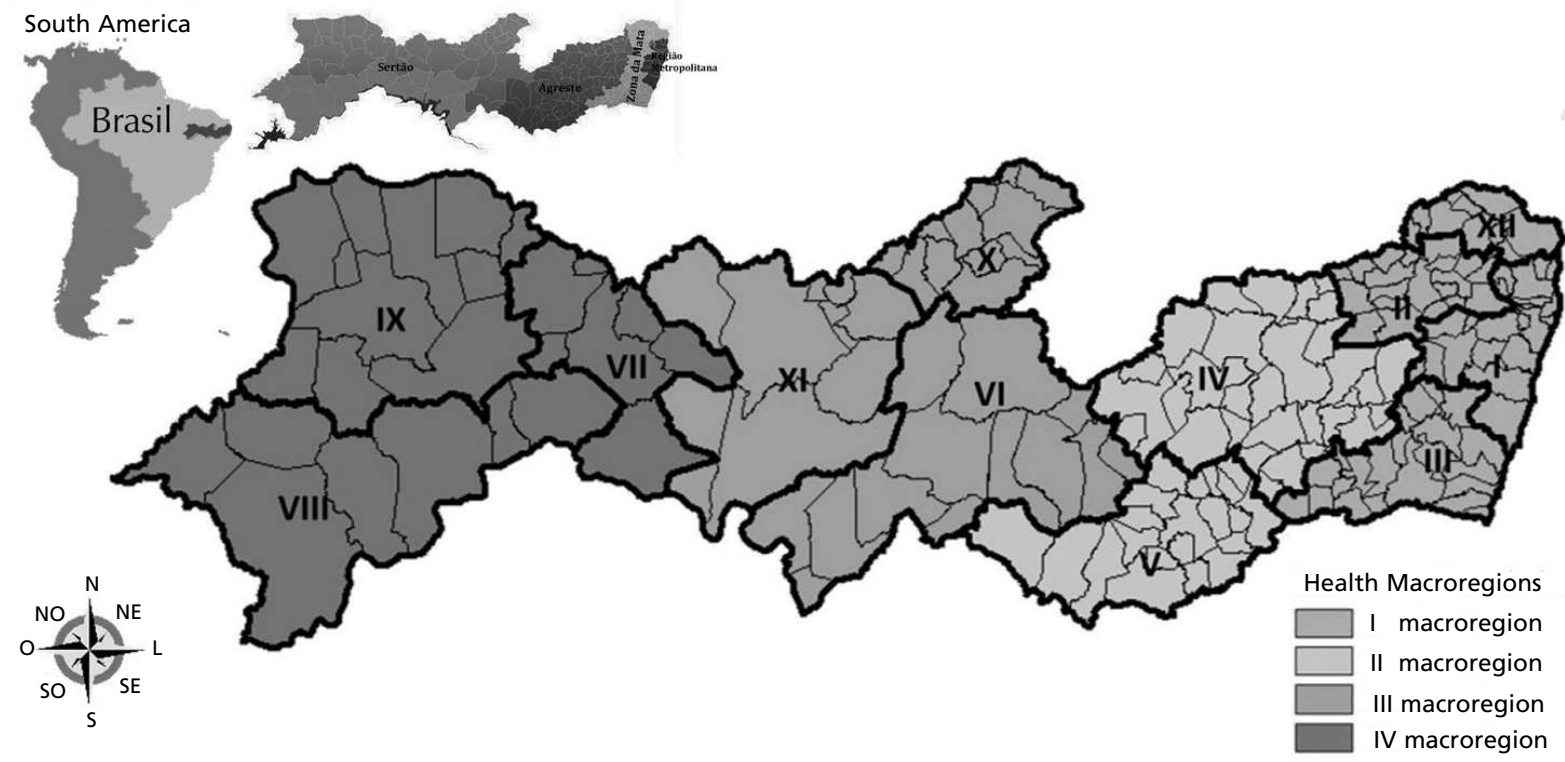


From the data analysis, graphics were created on Excel ${ }^{\circledR}$ and the thematic maps on TerraView 4.2.2 software in order to better illustrate the cytopathological coverage in the State of Pernambuco.

The secondary database used to elaborate this study are of public domain and there are no detailed personal data of patients guaranteeing their confidentiality, and were discharged from the assessment by the Research Ethics Comitee, according to the Resolutions of National Health Council (CNS) no. 466, on December, 12th of 2012 and also no. 510, on April, 7th of 2016.

\section{Inequities scenario in the access to preventive examinations}

When analyzing the triennial mean on cytopathological coverage in the State and in its Health Regions (Figure 2), it is possible to identify a triennial coverage for 2002-2004 predominantly below 0.20. In the following triennial (2005/2007), there is a slight increase in the coverage. Between 2008 and 2010, the State achieves the highest coverage (nearly 0.60) along the thirteen years. Between 2001 and 2013 there is a fall (below 0.50) that remained in this position for the last two years (2014 and 2015).

Regarding the mean in the Health Region, in the first triennials (2002/2004 and 2005/2007) the Regional and State mean were equated. However, from the third triennial (2008/2010) on, an expressive change takes place in this scenario: a mean of the region becomes different from the States and among themselves. In the outback of Afogados da Ingazeira region $(\mathrm{X})$ calls the attention of overlapping others by having a mean coverage over 0.80 , with an increased tendency for the following triennials. On the other hand, Petrolina (VIII) and Ouricuri (IX) presented a downfall after the 2008/2010 triennial, reaching a coverage below 0.20 in the last biennial (Figure 2).

When analyzing the cytopathological examination distribution coverage per city in 2002 (Figure 3 ), was observed that all 184 cities and towns including the insular district of Fernando de Noronha emphasized on a coverage below 0.4 , of

Figure 2

Means of triennial coverage on cytopathological examination according to Geres. Pernambuco, 2002-2015.

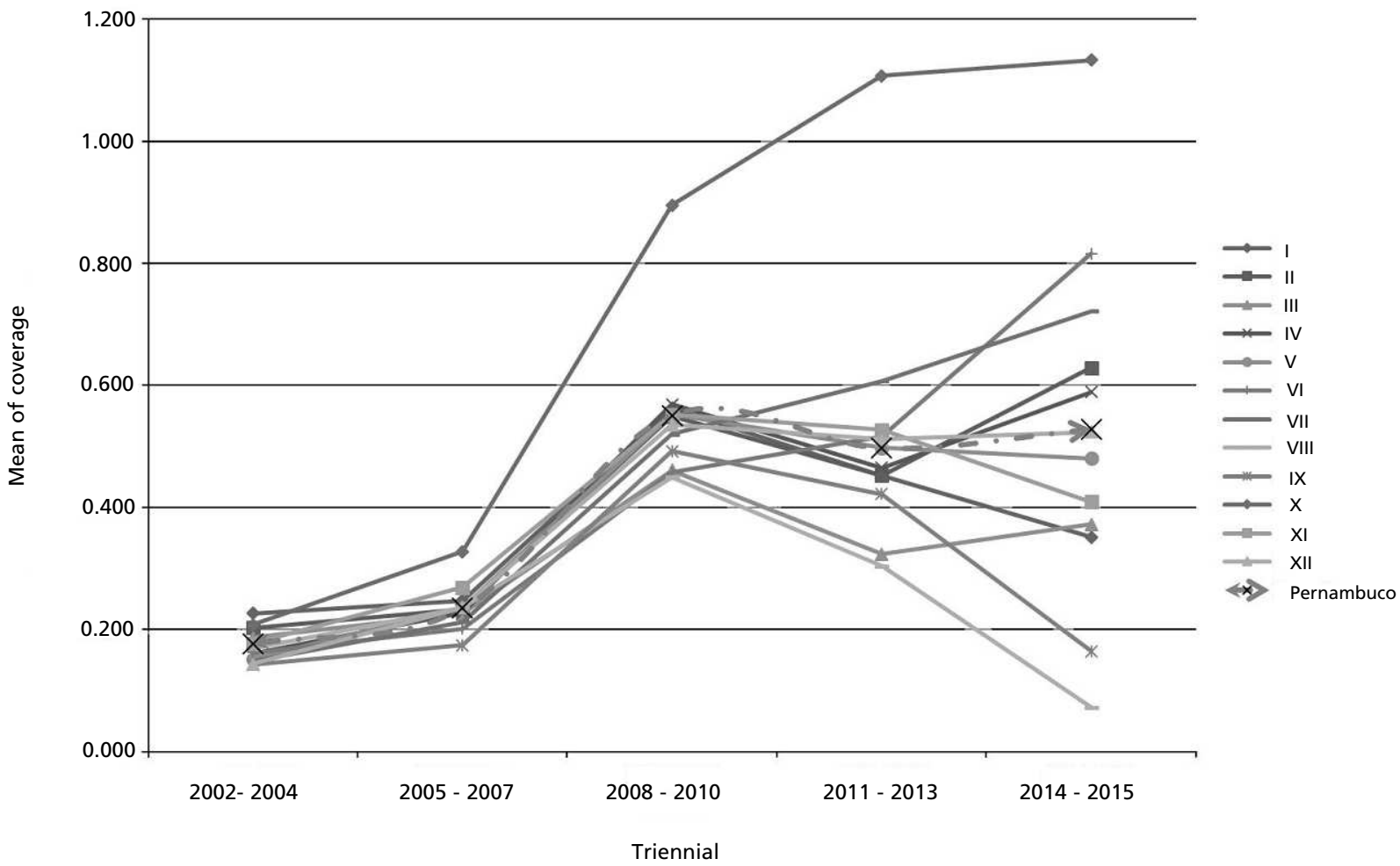


these, 79 cities and towns were below 0.2. In 2015, there was an important increase in the preventine coverage in 76 cities and towns with high /too high coverage (above 0.6 ) and 44 were classified as median coverage ( 0.4 to 0.6 ). Nevertheless, 25 cities and towns still present a low or very low coverage (less than 0.4 ), which reinforces the necessity of paying more attention to these locations, despite the improvements in the State scenario (Figure 3).
When analyzing the annual trend for the last fourteen years (Figure 4), it was possible to notice that from 184 cities and towns including insular district of Fernando de Noronha, 173 (94,0\%) obtained a increased trend of growth, statiscally significant, in terms of cytopathological examination coverage along its historical series. However, the situation in 12 cities and towns present a concerning negative growth trend.

It is noticeable that from the regression analysis

Figure 3

Distribution of cervical cytopathological examination coverage according to cities and towns. Pernambuco.

A
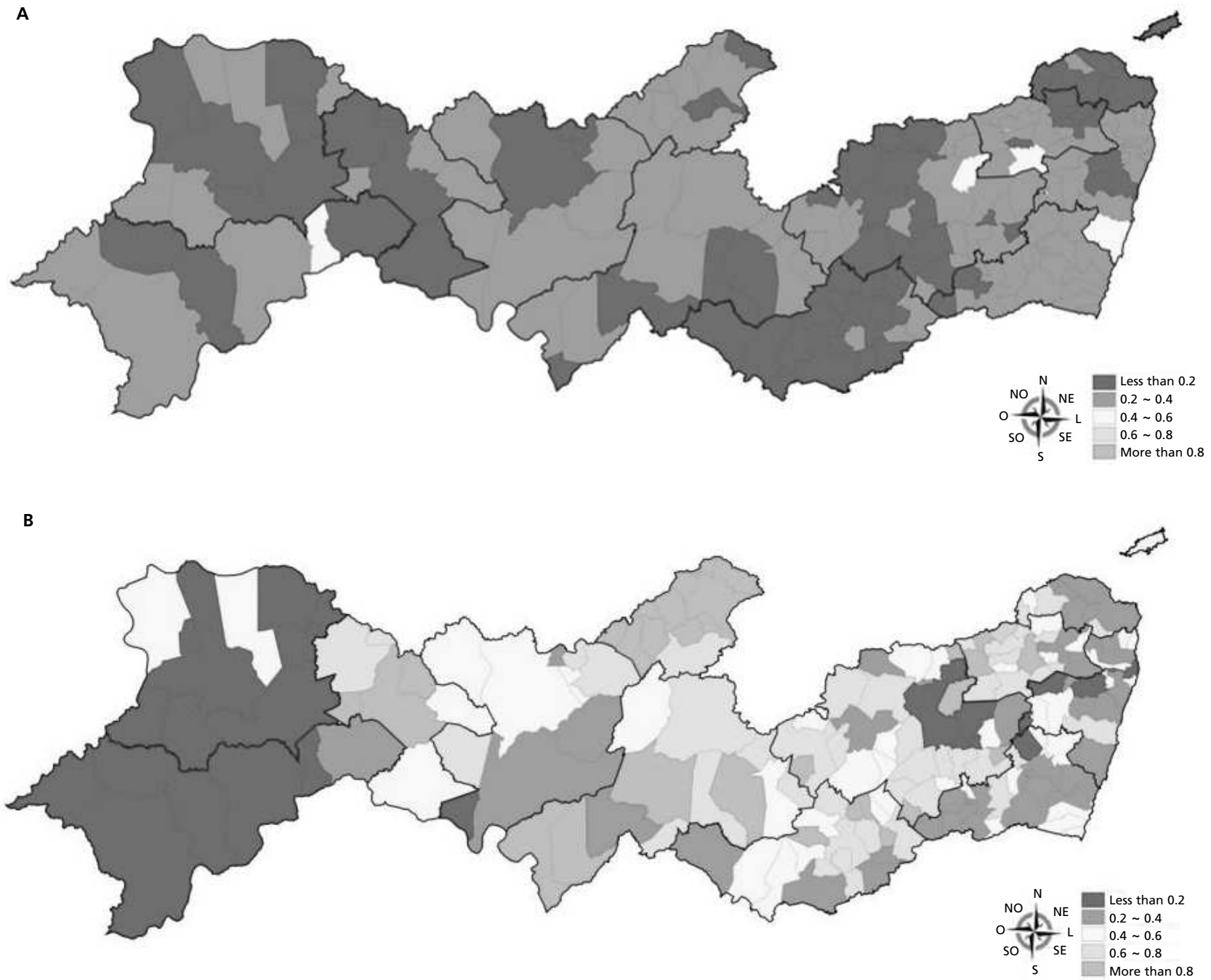

$A=$ Coverage of cervical cytopathological exams in 2002; B= Coverage of cervical cytopathological exams in 2015. 


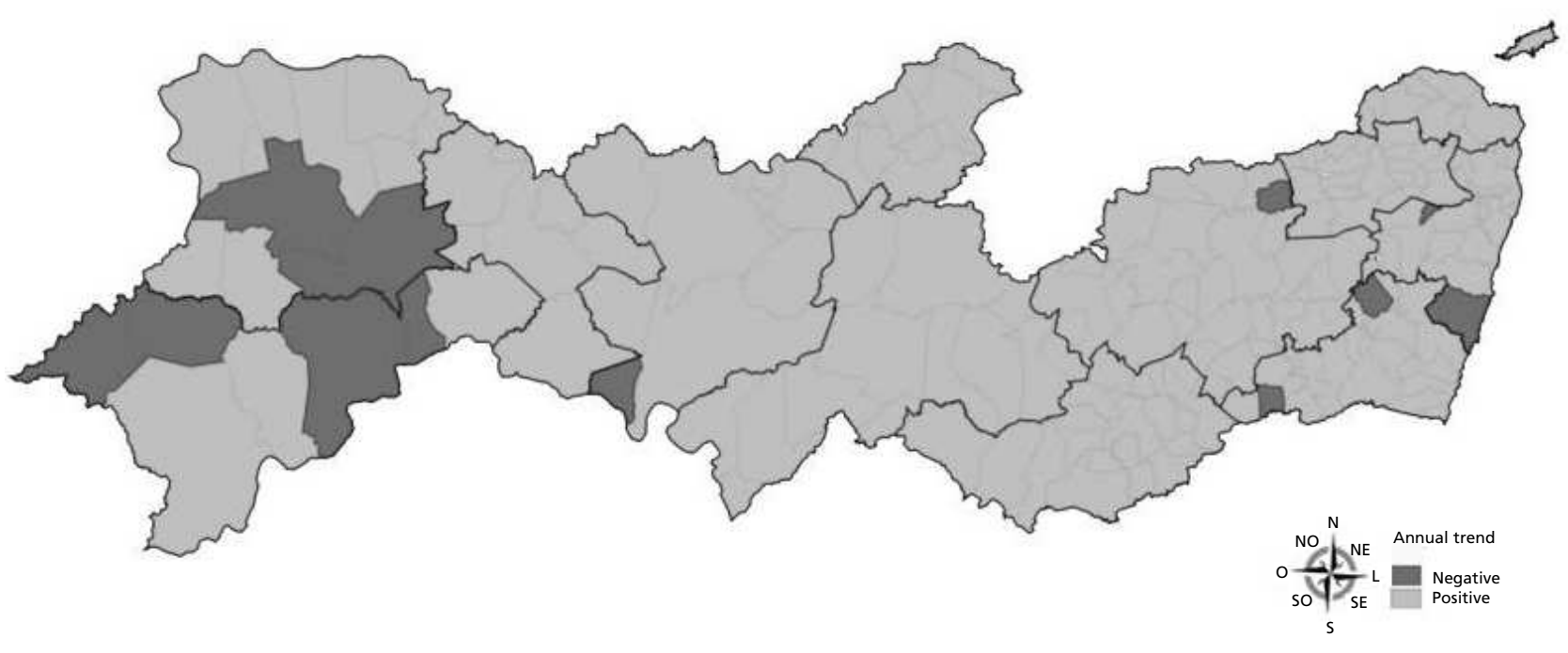

and its hypothetical statistic tests (Tests $F$ and $t$ ), there is an increasing growth in the State on cytopathological coverage over the last fourteen years (Figure 4), with a significant growth value $(p<0.05)$.

\section{Reflections on inequality in accessing and the challenges for the coverage extension}

As observed in the findings of this study, between 2002 and 2010, the indicator had grown and the regions of the triennial coverage mean were equated, despite still falling short of the coverage recommended by World Health Organization. ${ }^{7}$ Upon the following triennial (2011 to 2013), a gradual decline on some regions is evident, as well as the difference among them.

The increased coverage observed for the first triennials might have been driven by the expansion to access the Atenção Primária à Saúde (APS) (Primary Health Care) in the country, 17 associated with several federal actions to encourage prevention and control on cervical cancer, as the Programa Nacional de Combate ao Câncer de Colo Uterino (1998), 5 (National Program to Combat Cervical Cancer), Pacto pela Saúde (2006), 8 (Pact for Health), Decreto 7.508 (2011), 9 (The Decree) as well as the Plano de Enfrentamento de Doenças Crônicas 2011-2022 (2011), 18 (Confronting Chronic Diseases Plan) which established the $85 \%$ goal for examina- tion coverage.

On the other hand, such initiatives, even though related to firm commitments at State level,11,12 they were not enough to continue the coverage expansion for years ahead, which demonstrates a problematic scenario, especially in the outback of Pernambuco, the region where its coverages were the worst over the years. Petrolina (VIII) and Ouricuri (IX) regions are the most negative regions since they continued to be classified as having the lowest coverage in the State. The context regarding VIII region is the most concerned one, due to fact that it corresponds to a macroregion, and therefore, is responsible for a more structured service for the cities and towns. Moreover, it is stated in the database systems that this region is one of the few in the State to offer all the procedures for cervical cancer care. 18

It is noteable to point out the isolated expansion of cytopathological coverage is not sufficient to reduce the morbity and mortality indicators in cervical cancer. The quality of the material collected and its subsequent analysis are fundamental in providing a reliable result, which avoids false-negative result. In this matter, according to Santos et al.,19 during the period of 2006 and 2009, Pernambuco was among the States with the highest percentage of unsatisfying samples. The quality, as the collecting and the preventive laboratorial analysis are crucial for a precise diagnosis in order to guarantee adequate follow up for the women. 20 
The situation in the State is fragile when associating the findings in this study to the obtained results from Lira`s research, ${ }^{21}$ which points out the highest incidence of atypias in the cytopathological examinations were concentrated in the regions located in the outback of the State.

The decreased indicator tendency and several patterns among the health regions in the State, might be interpreted based on the issues that were highlighted in previous studies, as for the difficulty in having access to APS and/or the resistence of women to perform the exam with fear, shame or embarassment, besides the lack of knowledge regarding how the procedure is important. ${ }^{22,23}$ Although, it is necessary to note that these factors are concentrated on women in vulnerable conditions.

The social inequities are related both to a low cytopathological coverage and the highest mortality rates.24,25,26 When verifying the Índice de Desenvolvimento Humano (IDH) 27 in the State and the Health Region, it is noteable that Pernambuco is classified in an intermediate range in development, and nearly half of the region was classified having the lowest index. Regarding to Petrolina (VIII) and Ouricuri (IX) regions, a low coverage convergence of HDI was observed in these regions. Although, the VIII region demonstrates an intermediate HDI, detailing the index by the city and town, observing that most of them are below the HDI. This comparison reinforces the relation between social inequality and health access.

Another aspect to take into account, is the fact that this study is based on secondary database. These sources may present an overloaded or underreported data due to inadequate feeding from the information systems. Such fragility might result in the indicators values that may not relate to the real situation. The result in Afogados da Ingazeira (X), for example, points out the necessity for further detailed research in this region to understand atypia (coverage above 1.0) that was observed in the past years.

Despite positive result in some cities analyzed in the last year, when compared to the first scenario, it is noteable that the best results were concentrated in cities and towns closer to the capital (Metropolitan and Florest regions). Girianelli et al.28 study reinforces the understanding about the inequality of people who live distant from large urban centers to have access to health. The authors affirm that in the Northeast, mortality rates on cervical cancer are decreasing only in its capitals, while there was an increase in the number of mortality in the towns in the countryside.

Another factor that can also contribute to the low coverage established by the $\mathrm{WHO}$ is the procedure performed in the private health system, as pointed out by a previous study developed by Brio-Silva et $a l .{ }^{2}$ This study implies that the research development contemplate on the coverage calculation estimates and the supplementary health participation should also be taken into consideration.

The State of Pernambuco, during the period of 2002 to 2015, increased approximately, in populational terms, from 8.0 to 9 millions inhabitants. In regard to women, the growth was $11.8 \%$ and the age range of 25 to 64 years old increased to $24.0 \% .13$ Although, the increase of female population of this age group, the State also had a general tendency for the expansion coverage indicator in the State, from 0.18 in 2002 to 0.53 in 2015 , which represents an increase in the access to preventive examination. Nevertheless, the indicator settings are very heterogenious when relating to smaller territorial levels.

Despite the recommendations and the relevance of the indicator, the present study indicates that all regions at sometime or in all times present less coverage than expected, which implies the need to identify the factors that define this scenario so that the expansion may widen for everyone to have access to preventive examination.

The situation observed in Pernambuco, especially in the outback, is a great concern and requires the development of strategies that enable changes in this scenario. It is also suggested the development of the studies with a qualitative or mixed approach that can contribute to a better understanding of the dynamics in the Health Regions in Pernambuco, improving the dimension of factors related to a low cytopathological coverage.

\section{Authors' contribution}

Brito Silva KS and Leite AFB contributed to the concept and planning of this work, the analysis and interpretation of the data. Silva DMC also contributed to the analysis and interpretation of the data. Tanaka OY, Louvison M and Bezerra AFB contributed to the critical review of the content. All authors approved the final version of the manuscript. 


\section{References}

1. INCA (Instituto Nacional de Câncer José Alencar Gomes da Silva). Estimativa 2020: incidência de câncer no Brasil Rio de Janeiro: INCA; 2019. Disponível em: https://www.inca.gov.br/sites/ufu.sti.inca.local/files/media/ document/estimativa-2020-incidencia-de-cancer-nobrasil.pdf

2. Brito-Silva K, Bezerra AFB, Chaves LDP, Tanaka OY Integralidade no cuidado ao câncer do colo do útero: avaliação do acesso. Rev Saúde Pública. 2014; 48 (2): 240-8.

3. Correa MS, Silveira DS, Siqueira FV, Facchini LA, Piccini RX, Thumé E, Tomasi E. Cobertura e adequação do exame citopatológico de colo uterino em estados das regiões Sul e Nordeste do Brasil. Cad Saúde Pública. 2012; 28 (12): 2257-66.

4. Barbosa IR, Souza DLB, Bernal MM, Costa ICC Desigualdades regionais na mortalidade por câncer de colo de útero no Brasil: tendências e projeções até o ano 2030 Ciênc Saúde Coletiva. 2016; 21 (1): 253-62.

5. INCA (Instituto Nacional de Câncer José Alencar Gomes da Silva). Diretrizes brasileiras para o rastreamento do câncer do colo do útero. Rio de Janeiro; 2016. Disponível em:

https:/www.inca.gov.br/sites/ufu.sti.inca.local/files//media/ document//diretrizesparaorastreamentodocancerdocolodoutero_2016_corrigido.pdf

6. Brasil. Ministério da Saúde. Controle dos cânceres do colo do útero e da mama. 2 ed. Brasília, DF; 2013. Disponível em: http://bvsms.saude.gov.br/bvs/publicacoes/controle canceres_colo_utero_2013.pdf.

7. WHO (World Health Organization). Information Centre on Human Papilloma Virus (HPV) and Cervical Cancer: Human papillomavirus and related cancers in Brazil. Nova York; 2010. Disponível em: www.who.int/hpvcentre.

8. Brasil. Ministério da Saúde. Portaria n. 325, de 21 de fevereiro de 2008. Estabelece prioridades, objetivos e metas do Pacto pela Vida para 2008, os indicadores de monitoramento e avaliação do Pacto pela Saúde e as orientações, prazos e diretrizes para a sua pactuação. Brasília, DF; 2008. Disponível em: http://bvsms.saude.gov.br/bvs/saudelegis/ gm/2008/prt0325_21_02_2008.htm

9. Brasil. Ministério da Saúde. Decreto no 7.508, de 28 de junho de 2011. Regulamenta a Lei no 8.080 , de 19 de setembro de 1990, para dispor sobre a organização do Sistema Único de Saúde - SUS, o planejamento da saúde, a assistência à saúde e a articulação interfederativa, e dá outras providências. Brasília, DF; 2011. Disponível em: http://www.planalto.gov.br/ccivil_03/_ato20112014/2011/decreto/D7508.htm

10. Pernambuco. Secretaria Estadual de Saúde. Metas e resultados dos indicadores PACTO/COAP 2014. Recife; 2014.

11. Pernambuco. Secretaria Estadual de Saúde. Plano estadual de saúde 2008-2011: Pernambuco para todos. Recife; 2009. Disponível em: http://portal.saude.pe.gov.br/ sites/portal.saude.pe.gov.br/files/plano_estadual_de_saude 2008-2011.pdf.
12. Pernambuco. Secretaria Estadual de Saúde. Versão preliminar do Plano estadual de saúde 2012-2015. Recife; 2012. Disponível em: http://www.saude.pe.gov.br/arquivos/ Versao\%20Preliminar\%202012\%20-\%202015.pdf.

13. Pernambuco. Secretaria Estadual de Saúde. Perfil Socioeconômico, Demográfico e Epidemiológico: Pernambuco 2016. Recife: SES-PE; 2016. 238p. Disponível em:

http://portal.saude.pe.gov.br/sites/portal.saude.pe.gov.br/fil es/perfil_socioeconomico_demografico_e epidemiologico_de_pernambuco_2016.pdf.

14. Brasil. Ministério da Saúde. Caderno de diretrizes, objetivos, metas e indicadores: 2013-2015. Brasília, DF; 2015. Disponível em: http://bvms.saude.gov.br/bvs/publicacoes/ caderno_diretrizes_objetivos_2013_2015.pdf.

15. Brasil. Ministério da Saúde. Indicadores de Saúde e Pactuações. Brasília, DF; 2015. Disponível em: http://datasus.saude.gov.br/informacoes-desaude/tabnet/indicadores-de-saude.

16. Peternelli LA. Testes de Significância. In: Peternelli LA. Material didático INF162: Estatística I. Viçosa: UFV; 2004. Cap. 06, p. 77-88. Disponível em: http://www.dpi.ufv.br/ peternelli/inf162.www.16032004/m ateriais/CAPITULO6.pdf.

17. Pinto LF, Giovanella L. Do Programa à Estratégia Saúde da Família: expansão do acesso e redução das internações por condições sensíveis à atenção básica (ICSAB). Ciênc Saúde Coletiva. 2018; 23 (6): 1903-14.

18. Brasil. Ministério da Saúde. Plano de ações estratégicas para o enfrentamento das doenças crônicas não-transmissíveis (DCNT) no Brasil 2011-2022. Brasília, DF; 2011. (Série B. Textos Básicos de Saúde). Disponível em: http://bvsms.saude.gov.br/bvs/ publicacoes/plano acoes_enfrent dent 2011.pdf.

19. Santos RS, Melo ECP, Santos KM. Análise espacial dos indicadores pactuados para o rastreamento do câncer do colo do útero no Brasil. Texto Contexto-Enferm. 2012; 21 (4): 800-10.

20. Silva DSM, Silva AMN, Brito LMO, Gomes SRL, Nascimento MDSB, Chein MBC. Rastreamento do câncer do colo do útero no Estado do Maranhão, Brasil. Ciênc Saúde Coletiva. 2014; 19 (4): 1163-70.

21. Lira CRS. Serviços de saúde voltados ao câncer do colo uterino em Pernambuco: um olhar a partir dos sistemas de informações em saúde [monografia]. Recife: Centro de Pesquisas Ageu Magalhães da Fundação Oswaldo Cruz; 2015

22. Silva MAS. Teixeira EMB, Ferrari RAP, Cestari MEW, Cardelli AAM. Fatores relacionados a não adesão à realização do exame de Papanicolau. Revista Rene. 2015; 16 (4): 532-9.

23. Ferreira MLSM. Motivos que influenciam a não-realização do exame de papanicolaou segundo a percepção de mulheres. Esc Anna Nery. 2009; 13 (2): 378-84

24. Müller EV, Biazevic MGH, Antunes JLF, Crosato EM. Tendência e diferenciais socioeconômicos da mortalidade 
por câncer de colo de útero no Estado do Paraná (Brasil), 1980-2000. Ciênc Saúde Coletiva. 2011; 16 (5): 2495-500.

25. Barbosa I, Costa I, Pérez M, Souza D. As iniquidades sociais e as disparidades na mortalidade por câncer relativo ao gênero. RCP. 2015; 1 (2): 79-86.

26. Barcelos MRB, Lima RCD, Tomasi E, Nunes BP, Duro SMS, Facchini LA. Qualidade do rastreamento do câncer de colo uterino no Brasil: avaliação externa do PMAQ. Rev Saúde Pública. 2017; 51: 67.
27. Programa das Nações Unidas para o Desenvolvimento; Instituto de Pesquisa Econômica Aplicada; Fundação João Pinheiro. Atlas do desenvolvimento humano no Brasil. Brasília: PNUD; IPEA; FJP; [2013]. Disponível em: http://www.atlasbrasil.org.br.

28. Girianelli VR, Gamarra CJ, Silva GA. Os grandes contrastes na mortalidade por câncer do colo uterino e de mama no Brasil. Rev Saúde Pública. 2014; 48 (3): 459-67.

Received on May 20, 2019

Final version presented on January 16, 2020

Approved on March 4, 2020 